\title{
1917 Ekim Devrimi Sonrası Güney Kafkasya’da Gelişmeler Işı̆̆ında Ömer Faik Numanzade’nin Siyasi Faaliyetleri*
}

\section{Political Activities of Ömer Faik Numanzade in Line with the Events in the South Caucasus After the 1917 October Revolution}

\author{
Cafer Mustafal $1^{1}$ (i)
}

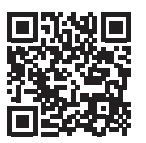

*Bu çalıșma "Kafkasya Türklerinden Ömer Faik Numanzade'nin Hayatı ve Faaliyetleri (18721937)" başlıklı yüksek lisans tezinden türetilmiştir.

'Sorumlu yazar/Corresponding author: Cafer Mustafalı (Doktora Öğrencisi), İstanbul Üniversitesi Türkiyat Araştırmaları Enstitüsü, İstanbul, Türkiye

E-posta: caferargunhan@gmail.com ORCID: 0000-0001-6612-1858

Başvuru/Submitted: 27.05.2020 Revizyon Talebi/Revision Requested: 20.08.2020

Son Revizyon/Last Revision Received: 05.09.2020

Kabul/Accepted: 05.09.2020

Atıf/Citation: Mustafali, Cafer. "1917 Ekim Devrimi Sonrası Güney Kafkasya'da Gelişmeler Işığında Ömer Faik Numanzade'nin Siyasi Faaliyetleri.", Avrasya Incelemeleri Dergisi - Journal of Eurasian Inquiries 9, 2 (2020): 283-299. https://doi.org/10.26650/jes.2020.018

\section{öz}

I. Cihan Harbi'nin başlamasından sonra Osmanlı Devleti'nin en önemli maksatlarından birisi Kafkasya'da Müslüman-Türklerin yoğunlukta oldukları bölgeleri sınırları içerisine katıp yerli Türklerin de desteğini kazanarak Türkistan'a açılmaktır. Ancak Osmanlı bu politikasında başarısız olmuş, hatta Ruslar Anadolu'nun içlerine kadar ilerlemişlerdir. 1917 Rus îtilalinden sonra bölgede gelişen olaylar Osmanlı Devleti'ni yeniden Kafkasya'ya yönlendirmiştir. 1917 yllında Bolşeviklerin iktidara gelmesinden sonra Rus birlikleri Kafkasya'dan çekilirken bölgedeki silah ve mühimmatlarını Gürcü milislere ve Ermeni çetelerine bırakmışlardır. Bundan dolayı Güney Kafkasya Türkleri işgal ve katliamlara karşı örgütlenerek siyasi faaliyetlere hız kazandırmışlardır. Ayrıca ismi pek zikredilmese de 1918 yılında Osmanlı Kafkas İslam Ordusunun Güney Kafkasya'ya girmesini sağlayan önemli aydınlardan birisi Gürcistan Türklerini temsil eden Ahıskalı Ömer Faik Numanzade olmuştur. Numanzade, I. Cihan Harbi sırasında bölgede gelişen olaylar üzerine Kafkasya ve Doğu Anadolu Türklerinin Rus, Ermeni ve Gürcüler karşısında yok olmaması için siyasi faaliyetlere girişmiştir. Bunun için İstanbul'da bulunmuş, Enver ve Talat Paşa ile görüşerek milli talepleri dile getirmiştir. Kafkasya Türklerinin varlıklarını koruyabilmeleri için Osmanlı'yı bölgeye davet etmiş, Kafkas İslam Ordusunun Kafkasya'ya gitmesine vesile olmuştur. 29 Ekim 1918 tarihinde kısa ömürlü de olsa Ahıska Hükûmeti kurulmuş, Ömer Faik bu hükûmetin başkanlığını yapmıştır. Bu konuyla ilgili bu güne kadar kayda değer bir çalışma yapılmamıştır. Bu bağlamda Kafkasya Türklerinin milli mücadele tarihinde mühim işler yapmış olan Ömer Faik Numanzade görmezden gelinmiştir. Bu çalışmada 1917 Ekim Devrimi'nden sonra Kafkasya'daki gelişmeler sonucunda ortaya çıkan tablo ve Ahıska Türklerini temsil eden Ömer Faik Numanzade'nin yürüttüğü siyasi faaliyetler ele alınacaktır. Çalışacağımız konu Gürcistan Türklerini kapsadığı için Türkiye ve Azerbaycan'ı ilgilendiren önemli meselelerdendir. Bu çalışma Gürcistan Türkleri açısından o döneme dair karanlık meseleleri aydınlatacak ve Türkiye'nin Kafkasya ile olan ilişkilerine ışık tutacaktır.

Anahtar kelimeler: Kafkasya, Osmanlı, Rusya, Ahıska, Ömer Faik Numanzade 


\begin{abstract}
After the outbreak of World War I, one of the most important goals of the Ottoman Empire was to dominate the areas where Muslim Turkish population was high in the Caucasus, thus gaining the support of indigenous Turks and opening up the way to Turkestan. However, the Ottoman Empire failed in this policy and the Russians advanced into the interior of Anatolia. The events that took place in the region after the Russian Revolution of 1917 re-directed the Ottoman Empire to the Caucasus. After the Bolsheviks came to power in 1917, Russian troops withdrew from the Caucasus and left their weapons and ammunition to the Georgian militia and Armenian gangs. Therefore, the South Caucasus Turks organized themselves against the occupation, and massacres occurred which accelerated political activities. One of the prominent figures in the Ottoman Caucasus Islamic Army in 1918 was Omer Faik Numanzade, who represented the Turks of Georgia. Numanzade undertook political activities in order to ensure that the Turks of the Caucasus and Eastern Anatolia did not disappear in the face of the Russians, Armenians and Georgians after the events that took place in the region during the First World War. For this purpose, he went to Istanbul and met with Enver and Talat Pasha and made some national demands. He invited the Ottomans to the region in order to protect the presence of the Caucasian Turks and to help the Caucasus Islamic Army to go to the Caucasus. On October 29, 1918, the Akhishka government was established, albeit short-lived, and Omer Faik was the president of this government. Considerable research has been carried out on this subject to this day. However, the studies conducted in the period in question mainly deal with Azerbaijan and Kars, while the Turks of the Ahıska Region or Georgia were not given much mention. Thus, Omer Faik Numanzade, who carried out important exploits in the history of the Caucasus Turks' national struggle, has largely been ignored. In this study, the picture that emerged as a result of the developments in the Caucasus after the October Revolution of 1917 and the political activities carried out by Omer Faik Numanzade representing the Georgian Turks (Ahıska) will be discussed. In this study, the description of the events that took place in Georgia will illuminate the darkness of that period and shed light on the relations within Turkey's Caucasus regions.
\end{abstract}

Keywords: Caucasus, Ottoman, Russia, Ahıska, Ömer Faik Numanzade

\title{
EXTENDED ABSTRACT
}

Omer Faik Numanzade, who was involved in many media activities in the cities of Tbilisi and Baku in the Caucasus between 1903 and 1911, returned to his hometown Ahiska after 1911. Numanzade carried out much needed work in the field of education and culture in Ahiska between 1911 and 1917. In this way, he prepared a kind of infrastructure for social and political developments in that town. He invited teachers from Azerbaijan to Ahiska and established courses for teachers within his capacity as member of the Ahıska National Committee (Ahıska Muslim Society). Sadly, these activities were very short-lived due to the start of the First World War in 1914 when the Russian Army began to carry out acts of destruction in Eastern Anatolia and in the Ahiska region. Therefore, the people of the region experienced great difficulties. In addition, during this period, Armenian gangs carried out persecution and massacres against Muslim Turks. All these developments became a significant milestone in Omer Faik's life.

After the Brest-Litovsk Treaty was signed on March 3, 1918 and the Erzincan Armistice on December 18, 1917, Russian military units began to withdraw from the Eastern Anatolia Region and the Caucasus. However, the Russians armed the Armenian gangs and Georgian units in their place. With the withdrawal of the Russians from the region, the Armenians created their own gangs and the Georgians increased their pressure against the Muslim Turks by forming 
their own militia. With the withdrawal of the Russian Army from the Caucasus, a complete political and administrative vacuum occurred in the region. Muslim Turks in the region, which had been subjected to Armenian and Russian persecution before, now took action in order not to be exposed to Georgian pressure and occupation and to gain their freedom.

After the events that took place in the region with the 1917 Russian Revolution, Omer Faik argued that the Caucasian Turks needed the Ottomans to protect their very existence, and he maintained that the Turkish army should annex the Caucasus. For this, he went to Istanbul to meet with Enver and Talat Pasha and express his requests. The contacts of Omer Faik in Istanbul worked well and he was instrumental in the Caucasian Islamic Army's gaining entry into the Caucasus. In addition, Numanzade asked Talat and Enver Pasha to combine Iranian Turks with Caucasian Turks. However, with the resignation of the Committee of Union and Progress on October 8, 1918 and the signing of the Mondros Armistice on October 30, 1918, the Turkish Army had to withdraw from the Caucasian territories except Elviye-i Selase. With the Armistice of Mondros, the Turks in the Caucasus were left alone, and the people of the region faced many difficulties.

Omer Faik Numanzade was involved in many important activities in order to gain the freedom and rights of Turks in Georgia as early as 1917 and he started to campaign for this cause. On October 29, 1918, the Ahıska Hükûmet-i Muvakkatası (Contemporary Ahıska Government) was established and Omer Faik Numanzade was elected as the president. The Ahıska Government, chaired by Omer Faik, joined the Kars Islamic Council, which was established in Kars on 5 November 1918. The Kars Islamic Council declared itself to be in power on 30 November. However, with the withdrawal of the Ottoman army from the region on December 4, 1918, the Georgians occupied Ahiska. The Kars Government declared the establishment of the Cenub-i Garbi (South West) Caucasian Government on 17 January 1919 to prevent Armenian and Georgian invasions. In this government, the Ahıskan Turks were also given the right to be represented. Moreover, the Muslim-Turkish troops belonging to this new formation took back the Ahıska region from the Georgians on 2 February 1919. Within a short space of time, the Ahiska region changed hands several times between the Turkish government in Kars and the Georgians. On April 22, 1919, with the intervention of the British in the region, the existence of the Southern Caucasus Government ended. With this, the Turkish domination in Ahiska also ended. 


\section{Giriş}

I. Cihan Harbi'nin başlamasından sonra Osmanlı Devleti'nin Kafkasya bölgesindeki önemli amaçlarından biri de Elviye-i Selase ${ }^{1}$ diye ifade edilen Kars, Ardahan ve Batum başta olmak üzere Kafkasya'da Ahıska ve Azerbaycan gibi Müslüman-Türklerle meskûn bölgeleri sınırları içerisine alarak yerli Türklerin de desteğini kazanıp Türkistan'a açılmaktır. Bu bağlamda Osmanlı Devleti Sarıkamış harekâtını gerçekleştirmiş ancak başarısız olmuştur. Hatta Ruslar Anadolu'nun içlerine kadar ilerlemişlerdir. ${ }^{2} 1917$ Rus İhtilalinden sonra Rusya'da ve bölgede gelişen olaylar Osmanlı Devleti'ni içine düştüğü karamsarlıktan çıkararak yeniden yüzünü Kafkasya'ya çevirtmiştir. Ekim Devrimi'nden sonra hâkimiyeti ele geçiren Bolşevikler Almanlarla anlaşma masasına oturmuşlar, 3 Mart 1918 tarihinde uzun müzakereler sonucu Brest Litovsk Antlaşmasını imzalamışlardır. Bu barış müzakerelerine Almanya’nın müttefiki olan Türkiye'de katılmış, Kars, Ardahan ve Batum bu antlaşmayla yeniden Türkiye'ye bırakılmıştır. ${ }^{3}$ Bolşevikler Brest Litovsk antlaşmasının neticesi olarak Osmanlı’yla Rusya arasındaki savaşı sonlandırmak maksadıyla 18 Aralık 1917 'de Erzincan mütarekesine imza atmışlardır. ${ }^{4}$ Bütün bu gelişmelerden sonra Rus askeri birlikleri Doğu Anadolu Bölgesinden ve Kafkasya'dan çekilmeye başlamıştır. ${ }^{5}$ Ancak Ruslar kendi yerlerine bölgedeki Ermeni çetelerini ve Gürcü birliklerini silahlandırmışlardır. Rusların bölgeden çekilmesiyle birlikte Ermeniler kendi çetelerini, Gürcüler ise kendi milis kuvvetlerini oluşturarak Müslüman Türklere karşı baskılarını artırmışlardır. ${ }^{6}$ Rus Ordusunun Kafkasya'dan çekilmesiyle birlikte bölgede tam bir siyasi ve idari boşluk oluşmuştur.

1917 Şubat İhtilalinden sonra Rusya’ da iktidara gelen Menşevikler 22 Mart 1917 tarihinde Kafkasya'da kendilerine yakın Mavera-i Kafkas Meclisi adında bir oluşum kurmuşlardır. Bu meclis ağırlıklı olarak Gürcü ve Ermenilerden meydana gelmekteydi. Mecliste çok az sayıda Azerbaycan Türkleri de vardı. Ekim 1917'de Bolşeviklerin Rus idaresini ele geçirmesinden sonra Kafkasya'daki bu oluşum Mavera-i Kafkas Hükümeti'ni kurduğunu ilan etmiştir. Bu hükümet kendini Büyük Rusya’nın bir parçası görmekle birlikte büyük çoğunluğu Gürcülerden meydana gelmekteydi. Nitekim bu hükümet Brest Litovsk mütarekesiyle Kars, Ardahan ve Batum'un Osmanlı'ya verilmesine karşı çıkarak bu kararı eleştirmişlerdir. Osmanlı Devleti'nin

1 "Üç sancak" anlamına gelen Elviye-i Selâse, Doksanüç Harbi'nden sonra, harp tazminatına karşılık olmak üzere Rusya'ya terkedilmeleriyle siyasî bir mesele olarak ortaya çıan Kars, Ardahan ve Batum sancaklarını ifade eder.

2 William Edward David Allen, Paul Muratoff, Kafkas Harekâtı (1828-1921): Türk-Kafkas Sinırındaki Harplerin Tarihi (Ankara: Genelkurmay Basımevi, 1966), 218-425.

3 Ahmet Ender Gökdemir, Cenub-i Garbi Kafkas Hükumeti (Ankara: Türk Kültürü Araştırma Enstitüsü Yayınları, 1989), 15.

4 Enis Şahin, Türkiye ve Maverâ-yı Kafkasya ilişkileri içerisinde Trabzon ve Batum konferansları ve Antlaşmaları (1917-1918) (Ankara: Türk Tarih Kurumu Yayınları, 2002), 154-172.

5 Mustafa Sarı, “Ahıska'da Son Osmanlı İdaresi (1918)”, Karadeniz Araştırmaları Dergisi 46 (Yaz 2015), 153 179.

6 Gökdemir, Cenub-i Garbi Kafkas Hükumeti, 19; Aktes Nimet Kurat, Türkiye ve Rusya (Ankara: Ankara Üniversitesi Basımevi, 1970), 325-338. 
Brest Litovsk Antlaşmasından sonra doğuya ilerleyerek işgal altındaki toprakları geri almak için mücadeleye başlaması, Trabzon ve Batum Konferansları Mavera-i Kafkas Hükümeti'ni aciz bir durumda bırakmıştır. Esasen üç büyük farklı milletten meydana gelen Mavera-i Kafkas Hükümeti'nin uzun süreli ayakta kalması mümkün değildir. Çünkü her üç milletin (Ermeniler, Gürcüler ve Türkler) kendisine göre sınırları ve siyasi hedefleri vardır. Bu yüzden merkezi Tiflis olan Mavera-i Kafkas Hükümeti 26 Mayıs 1918'de Tiflis şehrinde kendini feshetmiştir. Aynı gün Ermenistan ve Gürcistan bağımsızlıklarını ilan etmiş, iki gün sonra ise 28 Mayıs'ta Azerbaycan kendi istiklal beyannamesini yayınlamıştır. ${ }^{7}$

Ekim 1917'de Çarlık rejiminin devrilmesinden sonra yukarıda da ifade edildiği gibi Gürcüler ilk önce başında kendilerinin bulunduğu Mavera-i Kafkas Meclisi ve Mavera-i Kafkas Hükûmeti adındaki oluşumların içinde yer aldıktan sonra 26 Mayıs 1918 tarihinde kendi bağımsızlıklarını ilan etmiştir. Daha önce Ermeni ve Rus zulümlerine maruz kalmış bölgedeki Müslüman Türkler şimdi de Gürcü baskısına ve işgaline maruz kalmamak ve hürriyetlerini kazanmak maksadıyla harekete geçmişlerdir. Ömer Faik Numanzade, 1917 yılında itibaren Gürcistan'da Türklerin hürriyet ve haklarını kazanmaları için önemli faaliyetler içerisine girmiş ve bu uğurda mücadeleye başlamıştır. 29 Ekim 1918 tarihinde Ahıska Hükûmet-i Muvakkatası kurulmuş, başkan olarak Ömer Faik Numanzade seçilmiştir. Ömer Faik’in başkanlığını yürüttüğü Ahıska Hükûmeti 5 Kasım 1918 tarihinde Kars’ta kurulan ve daha büyük oluşum olan Kars İslam Şurası'na katılmışlardır. Kars İslam Şurası 30 Kasım'da kendisini hükûmet olarak ilan etmiştir. Ancak 4 Aralık 1918 yılında Osmanlı ordusunun bölgeden çekilmesi ile birlikte Gürcüler Ahıska'yı işgal etmişlerdir. ${ }^{9}$ Kars Hükûmeti Ermeni ve Gürcü işgallerini engellemek için 17 Ocak 1919 tarihinde Cenub-i Garbi Kafkas Hükûmet-i Muvakkatasını kurduklarını ilan etmişlerdir ${ }^{10} \mathrm{Bu}$ hükûmette Ahıska Türklerine de temsil hakkı verilmiştir. Nitekim bu yeni oluşuma ait Müslüman-Türk birlikleri 2 Şubat 1919 tarihinde Ahıska bölgesini Gürcülerden geri almışlardır. ${ }^{11}$ Kısa zaman içerisinde Ahıska bölgesi merkezi Kars'ta bulunan Türk hükûmetiyle Gürcüler arasında bir kaç defa el değiştirmiştir. ${ }^{12} 22$ Nisan 1919 tarihinde İngilizlerin bölgeye müdahalesiyle Cenub-i Garbi Kafkas Hükûmeti’nin varlığına son vermiştir. ${ }^{13}$ Bununla Ahıska'daki Türk hâkimiyeti de sona ermiştir.

7 Gökdemir, Cenub-i Garbi Kafkas Hükumeti, 19; Kurat, Türkiye ve Rusya, 466-480; Allen, Kafkas Harekâtı (1828-1921): Türk-Kafkas Sinırındaki Harplerin Tarihi, 426-460.

8 Şamil Gurbanov, Ömer Faik Numanzade (Bakü: Gençlik Yayınları, 1992), 114; Ömer Faik, “Ömer Faik Efendinin Ruhadze'nin Telegramına Cevabı", Azerbaycan, 9 Mart 1919, 2.

9 Gökdemir, Cenub-i Garbi Kafkas Hükumeti, 78.

10 Fahrettin Kırzıoğlu, "Cenûbu-Garbî Kafkas Cumhuriyeti (Kars Milli-Şûrâ Hükûmeti)”, Türk Kültürü 6/72 (1968), 961.

11 Gökdemir, Cenub-i Garbi Kafkas Hükumeti, 127.

12 Mustafa Sarı, “I. Dünya Savaşı’ndan Sonra Ahıska ve Civarında Türk Teşkilatlanması”, Yeni Türkiye 78 (Ekim 1918-Nisan 1919), 309-323.

13 Fahrettin Kırzıoğlu, Kars Tarihi, (İstanbul: Iş11 Matbaası, 1953), I: 558. 


\section{Rus Devrimi’ne Kadar Ömer Faik}

Ömer Faik Numanzade 1911-1917 yılları arasında Ahıska' da eğitim ve kültür sahasında birçok önemli işler yapmıştır. O bu yolla Ahıska' da içtimai ve siyasi gelişmelerin bir tür alt yapısını hazırlamıştır. ${ }^{14}$ Azerbaycan'dan Ahıska'ya öğretmenler davet etmiş, Ahıska Milli Komitesi'nin (Ahıska Müslüman Cemiyeti) terkibinde öğretmen kursları kurmuştur. Bütün bu işlerin başında da kendisi durmaktayd $1 .{ }^{15}$ Numanzade ayrıca bağış toplayıp bir yardımlaşma derneği kurarak I. Cihan Harbi’nde zarar gören Doğu Anadolu Türklerine yardım için ciddi faaliyetler içerisine girmiştir. ${ }^{16}$

1903-1911 yılları arasında Kafkasya'da Tiflis ve Bakü şehirlerinde basın yayın faaliyetlerinde önemli işleri başaran Ömer Faik Numanzade, yukarıda da ifade edildiği gibi 1911'den sonra memleketi Ahıska'da bulunmuştur. ${ }^{17} 1914$ yılında Birinci Cihan Harbi'nin başlamasıyla birlikte Doğu Anadolu'da ve Ahıska bölgesinde Rus Ordusu tahribat ve yıkımlar yapmıştır. Bundan dolayı bölge ahalisi çok büyük sıkıntılar yaşamıştır. Ayrıca bu dönemde Ermeni çeteleri Müslüman Türklere karşı zulüm ve katliamlar gerçekleştirmiştir. Bütün bu gelişmeler Ömer Faik' in hayatında bir dönüm noktası olmuştur. ${ }^{18}$

Ömer Faik, I. Cihan Harbi’nin ilk yıllarında Doğu Anadolu'daki Müslüman Türklerin içler acısı durumları nedeniyle bölge ahalisine yardım için önemli faaliyetlere girişmiştir. Bölgeyi karış karış gezen Ömer Faik savaş bölgesindeki kasabaların ve köylerin yaşadıklarına yakından şahit olmuştur. 1911 yılında 1915 yılına kadar Kafkasya matbuatında imzası görülmeyen Ömer Faik'in 1915'ten itibaren matbuat organlarına tekrar döndüğü görülmüştür. Onun bu tarihlerden itibaren yazmaya başladığı yazılarında ezilen Müslüman Türklere yardım etmek ve Kafkasya'da toplumsal duyarlılığg artırmak istediği hissedilmiştir. ${ }^{19} 1917$ yılında Bakü’ de Anadolu Türklerine yardım için çıkarılan Kardeş Yardımı dergisinde Türk Milliyetçiliği ile ilgili yazdığı "Ben Kimim” makalesinde o güne kadar hiç görülmemiş şekilde milliyetçilik duygularıyla dolu bir tarzda yazı kaleme almıştır. Aslında Numanzade bu yazısıyla Kafkasya Türklerinin milli mücadelesinin zamanı geldiğini ve bunun için Türklerin bir ve beraber olması gerektiğini ifade etmiştir. ${ }^{20}$

\section{Ahıska Delegesi Olarak İstanbul'a Gelişi}

Rusların verdiği silah ve mühimmatların sayesinde kendilerine milis kuvvetleri kuran Gürcüler ve Ermeniler Ruslardan boşalan arazileri ele geçirmek maksadıyla harekete geçmişlerdir.

14 Sahib Rzayev, Ömer Faik Numanzade'nin Edebi-Publist Faaliyeti, (Doktora Tezi, Azerbaycan İlimler Akademisi Nizami Adına Edebiyat Enstitüsü, 1973), 27.

15 Gurbanov, Ömer Faik Numanzade, 114.

16 Ömer Faik Numanzade, "Yardım Tecili Lazım", İkbal, 19 Yanvar [Ocak] 1915, 2-3.

17 Gurbanov, Ömer Faik Numanzade, 101-102.

18 Jafar Mustafaev, Kafkasya Türklerin den Ömer Faik Numanzade’nin Hayatı ve Faaliyetleri (1872-1937), (Yüksek Lisans Tezi, Marmara Üniversitesi Türkiyat Araştırmaları Enstitüsü, 2019), 82.

19 Şamil Gurbanov, Seçilmiş Eserler-Ömer Faik Numanzade (Bakü: Şark-Garb Yayınları, 2006), 183-204.

20 Ömer Faik Numanzade, "Ben Kimim?”, Gardaş Kömeyi [Yardımı] (Bakü: Müherrirler Neşriyatı, 1917), 11; Mustafaev, Kafkasya Türklerin'den Ömer Faik Numanzade 'nin Hayatı ve Faaliyetleri (1872-1937), 83. 
Onların ele geçirmek istedikleri yerlerin başında Ahıska ve civarındaki Müslüman Türklerin yerleşik bulunduğu arazileri vard. ${ }^{21}$ Kafkasya Türklerinin bütün bu gelişmeler çerçevesinde ayakta kalabilmelerini sağlayacak tek umutları Osmanlı Devleti idi. ${ }^{22}$

Bu sırada Güney Kafkasya'da Müslüman Türkler de boş durmamış, kendi varlıklarını korumak için teşkilatlanmışlardı. Türklerin bölgede Ruslar ve Ermenilere karşı faaliyetleri Müslümanların Güney Kafkasya'dan kolayca silinemeyeceğini göstermekteydi. ${ }^{23}$ Kafkasya Türkleri gelişen bu olaylar çerçevesinde Ermeniler, Gürcüler ve Ruslar arasında sıkışıp yok olmamak için Osmanlı Devleti'nden askeri yardım talep etmeye karar verdiler. Nitekim bunun için İstanbul'a bir heyet gönderildi. Azerbaycan Türkleri Naki Şeyhzamanlı'yı, Ahıska Türkleri ise Ömer Faik Numanzade'yi Osmanlı'ya yani Talat Paşa ve Enver Paşa'nın yanına temsilci olarak gönderdiler. Azerbaycan'ı temsilen yola çıkan Naki Şeyhzamanlı'nın yanında Osmanlı Devleti'nin subayı olan ve Ruslara esir düşen Hüsamettin Tuğaç da vardı. Bu kişiler tren yoluyla Gence'den Tiflis'e oradan da Batum'a gittiler. Bu sirada Ahıska'yı temsilen yola çıkan Ömer Faik Numanzade de Batum'da bulunmaktaydı. Güney Kafkasya Türklerini temsilen birbirlerinden bağımsız şekilde yola çıkan delegeler Batum'da bir araya geldiler. Naki Şeyhzamanlı hatıralarında Batum'a varışlarını ve Ömer Faik ile karşılaşmalarını şu şekilde anlatmaktadır:

“İstasyondan doğruca Batum Cemiyet-i Hayriye Reisi Doktor Mahmut Bey’e gittik. Maksadımızı anlattıktan sonra bizi emin bir şekilde Türkiye'ye geçirmesini rica ettik. Birlikte (Hüsamettin Tuğaç'la) doktorun evine gittik. Evde Tiflis’te intişar eden Molla Nasreddin Dergisin muharrirlerinden Ahıskalı Ömer Faik Bey ile görüştük. Doktor onun da Türkiye'ye gitmek istediğini bize önceden söylemişti." ${ }^{24}$

Naki Şeyhzamanlı ile beraber yola çıkan Teğmen Hüsamettin Tuğaç ise hatıralarında Ömer Faik ile karşılaşmasını şu şekilde aktarmaktadır:

“Acarların reisi sayılan Hamsizade Cemal Paşa da oğlu Celil Bey’i yanımıza kattı. Celil Bey Acara namına Türk Ordusunu davet etmek istiyordu. Doktor Mahmud Bey'in evinde rastladığımız Ahıskalı yazar ve öğretmen Ömer Faik Bey ve ayrıca Ahılkelekli Efraim Bey isimli bir zat da Ahılkelek adına aynı daveti yapmak istiyorlardı. Bu üç arkadaş karadan Trabzon'a gideceklerdi". ${ }^{25}$

Osmanlı' dan yardım almak amacıyla yola çıkan Kafkasyalı delegelerden Naki Şeyhzamanlı ile Hüsamettin Tuğaç deniz, Ömer Faik ve yanındakiler kara yoluyla Trabzon’a, oradan da

21 Sarı, “Ahıska'da Son Osmanlı İdaresi (1918)", 153-179.

22 Allen, Kafkas Harekâtı (1828-1921): Türk-Kafkas Sinırındaki Harplerin Tarihi, 426-430.

23 Naki Keykurun, Azerbaycan İstiklal Mücadelesinin Hatıralarl (1905-1920) (İstanbul: İstanbul Ekspress Matbaas1, 1964), 74-84; Hüsamettin Tuğaç, Bir Neslin Dramı (İstanbul: Çağdaş Yayınları, 1975), 185-195.

24 Keykurun, Azerbaycan Istiklal Mücadelesinin Hatıralarl (1905-1920), 87.

25 Tuğaç, Bir Neslin Dramı, 198. 
Tirebolu'ya geçmişlerdir. ${ }^{26}$ Naki Şeyhzamanlı Tirebolu'da Ömer Faik ile yaptığı diyaloğu hatıralarında şu şekilde aktarmaktadır:

\begin{abstract}
"Bir ara uykuda gibi kendi kendime söylemeye başladım: Eğer Türkiye’nin yardımını sağlar ve muvaffak olabilirsek istiklalimizi ilan eder ve müstakil oluruz. Böylece dünyaya ikinci bir Türkiye doğmuş olur. Daha sözlerimi bitirmemiştim ki Ömer Faik bomba gibi patladı: "Sen ne söylüyorsun. Sarıkamış’ta on binlerce şehit veren Türkiye Kafkasya'yı işgal etmeyecek de size istiklal verecek öyle mi?" Hem bağırıyor hem de beni tehdit ediyordu. Sen Osmanlı ricali ile görüşecek ve fikirlerini anlatacaksın öyle mi? Bu sözlerden sonra Ömer Faik firladı ve gitti. ${ }^{27}$
\end{abstract}

Ömer Faik I. Cihan Harbi sırasında Doğu Anadolu ve kendi memleketi olan Ahıska'da Türklere yapılan mezalimleri görmüş, yok olma tehlikesiyle karşı karşıya kaldıklarını fark etmiştir. Bundan dolayı bölgede var olmalarının yegâne yolunu Osmanlı' da görmüştür. Naki Şeyhzamanlı Osmanlı'nın yardımıyla bağımsız bir Azerbaycan isterken Ömer Faik ise Türk Ordusunun bölgeyi ilhak etmesinden yanayd1. ${ }^{28}$ Göründüğü kadarıyla İstanbul'a doğru beraber yola çıkan bu iki arkadaş Osmanlı' dan yapacakları taleplerle bağlı fikir ayrılıkları içerisindeydiler. Ayrıca Ömer Faik Numanzade'nin Naki Beyin bu sözlerine bu kadar ters bir tepki vermesi anlaşılır değildir. Belli ki Naki Bey hatıralarında ifade etmediği cümleler kurmuş, Numanzade'ye çok ağır gelen ve hiç bir şekilde kabullenemeyeceği bir şeyler söylemişti. ${ }^{29}$

Kafkasyalı delegeler Tirebolu'dan Giresun'a geçerek oradan da 3. Ordusu Komutanı Vehip Paşa'nın yanına yani Osmanlı Kafkas Cephesi karargâhının yerleştiği Suşehri’ne gittiler. ${ }^{30}$ Hüsamettin Tuğaç ile Vehip Paşa daha önceden tanışıyorlard1. ${ }^{31} \mathrm{Bu}$ sebeple Hüsamettin Tuğaç Kafkasya' dan birlikte yola çıktığı delegeleri Vehip Paşa'ya taktim eder. Yüksek rütbeli askerlerin de katılımıyla Ömer Faik, Naki Bey ve Vehip Paşa arasında bir görüşme olur. Bu görüşmeden sonra Vehip Paşa, Hüsemettin Tuğaç’tan Kafkasya’yla ilgili bir rapor yazmasını ister. Hüsamettin Tuğaç da bunun üzerine bir rapor hazırladılar. ${ }^{32}$ Vehip Paşa Kafkasyalı heyetin verdikleri bilgilerden ve Hüsamettin Tuğaç’ın yazdığg raporu okuduktan sonra Enver Paşa'yla "telgraf başında saatlerce konuşma" yaptılar. ${ }^{33}$

Vehip Paşa'nın görüşme esnasında sarf ettiği bir ifade Naki Şeyhzamanlı ve Ömer Faik Numanzade gibi milli hassasiyeti yüksek olan ve Türklükleriyle övünen bu kişileri şaşırtmış ve hayâl kırıklığına uğratmıştır. Vehip Paşa, Naki Şeyhzamanlı ile muhabbeti esnasında şu cümleleri sarf etmiştir:

26 Keykurun, Azerbaycan İstiklal Mücadelesinin Hatıraları (1905-1920), 92.

27 Keykurun, Azerbaycan Istiklal Mücadelesinin Hattraları (1905-1920), 92-93.

28 Bunu Ömer Faik Numanzade'nin İstanbul'a varmadan önce Anadolu'dayken Talat ve Enver Paşa'ya gönderdiği mektuptan anlıyoruz. Bkz. Giyas Şükürov, Vasif Gafarov, Azerbaycan Cumhuriyeti (1918-120) (İstanbul: Teas Press Yayınları, 2018), 57.

29 Mustafaev, Kafkasya Türklerin'den Ömer Faik Numanzade'nin Hayatı ve Faaliyetleri (1872-1937), 86.

30 Keykurun, Azerbaycan İstiklal Mücadelesinin Hatıraları (1905-1920), 93.

31 Tuğaç, Bir Neslin Dramı, 209.

32 Tuğaç, Bir Neslin Dramı, 209-212.

33 Tuğaç, Bir Neslin Dramı, 212-213. 


\begin{abstract}
"Ben bir buçuk yıldır Kafkas cephesi kumandanıyım. Kafkasyalıları tetkik ettim öğrendim. Siz Kafkasyalılar da, biz Arnavutlar gibi temizliği seviyorsunuz. Bu pis Türk neferlerini, hem de bu kılıkla Kafkasya'ya sokmam.

Ben beynimden vurulmuşa döndüm, hiç bir cevap veremedim. Arnavut: Bu kelime yabanc1 değil. Ancak yeryüzünde Arnavut diye bir milletin varlı̆̆ından haberdar değildim... Ancak Balkan savaşını takip ettiğimden, harp esnasında İşkodra'da Esat Paşa adındaki bir fırka komutanı Arnavutun Osmanlı'ya isyan ettiğini Rus gazetelerinden okumuştum". ${ }^{34}$
\end{abstract}

Kafkasya en başından beri Enver Paşa'nın ilgi gösterdiği bir bölge idi. Bundan dolayı Vehip Paşa'ya Kafkasyalı heyeti tez bir zamanda İstanbul'a ulaştırması konusunda talimat vermiş̧tir. Azerbaycan'ı temsilen Naki Şeyhzamanlı, Ahıska’yı temsilen Ömer Faik Sivas, Kayseri ve Ulukışla yolu ile İstanbul'a gönderilmiştir. İstanbul'a hareket eden Ömer Faik ile Naki Bey'in gittikleri güzergâh ve durumları her daim bölgelerdeki yetkili kurumlar tarafından telegraflar çekilerek payitahta bildirilmiştir. ${ }^{35}$ İstanbul'a doğru yola çıkan Ömer Faik ve Naki Bey, 2 Mart 1918 tarihinde İstanbul'a ulaşmışlardır. ${ }^{36}$

Ömer Faik'le Naki Beyi İstanbul'da karşılamak için eski Amasya mebusu Esat Bey diye birisi görevlendirmiştir. Esat Bey onları İstanbul'da Pere Palas otelinde kendilerine ayrılan dairelere yerleştirmiştir. Naki Şeyhzamanlı hatıralarında Tirebolu'da Ömer Faik'le ilhak ve bağımsızlık konusunda yaptıkları tartışmadan dolayı Ömer Faik'in ona kızgın olduğunu ve İstanbul'a kadar yüzüne bakmadığını hatta mecbur kalmadığı durumlarda kendisiyle konuşmadığını söylemektedir.

Osmanlı Devlet Erkânı ile görüşmelerine çok az bir zaman kalmasına rağmen Ömer Faik, Naki Beyle hiç bir istişare etmiyor, nasıl bir istek ve talepte bulunacağını bildirmiyordu. Naki Bey, Ömer Faik' in davranışını şöyle aktarmaktadır: "Saat beşte Talat Paşa ile görüşerek vazifemi yapacağım. Benim için hiç bir mani yok. Ömer Faik ise devamlı gazete okuyordu" ${ }^{37}$

Görüşme vaktine çok az bir zaman kala Naki Bey, Ömer Faik’e yaklaşarak Azerbaycan ile ilgili hiç bir şey söylememesini, bu konuda konuşmak için yetkinin kendisinde olduğu ve Ömer Faik'in sadece Ahıska'yla ilgili konuşma yapmasını rica eder.

"Faik Bey, "Biraz sonra sizinle birlikte Osmanlı Devlet Reisi ile görüşmeğe gideceğiz. Biliyorsunuz ki sizin vatanınız Ahıska'dır. Sizin ile bizim aramızda Gürcistan vardır. Sakın Gürcistan'dan öteye geçmeyiniz. Orası Azerbaycan'dır ve sizin ülkenizle hiçbir ilgisi yoktur. Orası hakkında söz söylemek yalnız benim salahiyetim dâhilindedir. Anlaşmazlığımıza burada son verelim. Benim söyleyeceğim sözlerin mesuliyeti bana aittir” dedim. Ancak Ömer Faik benim bu sözlerime hiç bir cevap vermedi." ${ }^{38}$

34 Keykurun, Azerbaycan Istiklal Mücadelesinin Hattralarl (1905-1920), 93-94.

35 Şükürov ve Gafarov, Azerbaycan Cumhuriyeti (1918-120), 52-55.

36 Mustafa Sarı, "Kafkas Murahhaslarının İstanbul Seyahati ve Kafkas Cephesi (1918)", Kafkas Çalış̧maları: Sosyal Bilimler Dergisi 2 (Mart 2016), 75-100.

37 Keykurun, Azerbaycan Istiklal Mücadelesinin Hattraları (1905-1920), 95-96.

38 Keykurun, Azerbaycan İstiklal Mücadelesinin Hatıralarl (1905-1920), 97. 
Naki Şeyhzamanlı'nın bu sözlerinden yola çıkarak Ömer Faik'in ona neden bu kadar kızgın olduğunu anlayabiliriz. Naki Bey, Vehip Paşa’nın ona söylediği ifadelerden dolayı çok üzüldüğünü ve kırıldığını söylemektedir. Ancak kendisinin Ömer Faik’e bu şekilde hitap etmesinin doğru olup olmadığı tartışılabilir. Çünkü Ömer Faik İstanbul'da eğitimini tamamlayıp Kafkasya'ya döndükten sonra bütün varlığg ile Azerbaycan için ve Azerbaycan Türkleri için çalışmış, hiç bir zaman kendisini Azerbaycan Türklerinden ayrı düşünmemiş veya hissetmemiştir. Ömer Faik' in onun bu ifadelerine daha sonra nasıl bir tepki verdiğini bilmiyoruz. ${ }^{39}$

Ömer Faik ve Naki Bey onlara bildirilen vakitte Bab-1 Alî’ye giderek Osmanlı Devlet Erkânının huzuruna çıktılar. Naki Bey bu görüşmeyi şu şekilde nakletmektedir:

\begin{abstract}
"Başta büyükçe bir masa vardı. Talat Paşa masanın arkasında, sağ tarafında Enver Paşa, sol tarafında Halil Bey (Menteşe) oturuyordu. Masanın ön tarafında ise iki boş koltuk vardı. Masaya yaklaştık, selamlaştık ve el sıkıştık. Koltukları gösterdiler, oturduk. (Naki Bey) ben itimatnamemi çıkarıp Talat Paşa'ya verdim. Aldı okudu. Mühürdeki ay-yıldızın güzelliğinden çok çok hoşlanmış olacak ki, itimatnamemi Enver Paşa ve Halil Beye göstererek "Mühürdeki ay-yıldızın güzelliğine bakınız" dedi”. ${ }^{40}$
\end{abstract}

Naki Şeyhzamanlı Azerbaycan'1 temsilen söz alır ve Azerbaycan Türklerinin istek ve taleplerini Devlet Erkânına iletir. Naki Bey meramını anlatıp bitirdikten sonra Ömer Faik söz alarak konuşmaya başlar:

\begin{abstract}
"Paşam ben muharririm. Azerbaycan matbuatında çok çalıştım. Azerbaycan halkı Türklüklerini bihakkın idrak etmiş bir millettir. İstiklale layıktırlar. Kuvvetli bir edebiyata maliktirler. Ancak benim ricam şu: Bizim kazamız Ahıska tam Osmanlı hududundadır. Orasının ilhakını istiyorum". ${ }^{41}$
\end{abstract}

Ömer Faik'in bu konuşması üzerine Talat Paşa: “Emin olun, Paşa Hazretleri (Enver Paşa'yı kastetmektedir) bu arzunuzu yerine getirdi. Yarın teşkilatı kurmaya başlayacağız" der. ${ }^{42}$ Bu görüşmede Osmanlı'daki Türk kardeşlerinden yardım sözü alan Naki Bey’le Ömer Faik "sevinç gözyaşlarıyla bir birlerine sarıldılar”. Bu görüşmenin hemen ardından Kafkasya Türklerine yardım için Kafkas İslam Ordusu'nun kurulması için hazırlıklara başlandı $1{ }^{43}$ Kafkasya Türklerinin istiklalini kazanmasında ve varlıklarını korumasında Osmanlı'nın bölgeye gönderdiği Kafkas İslam Ordusu inkâr edilemeyecek kadar önemliydi. Osmanlı'nın devlet yetkililerinin bilgilendirilmesinde ve Türk Ordusunun Kafkasya’ya gelmesi için yetkililerin ikna edilmesinde Naki Şeyhzamanlı ile Ömer Faik Numanzade'nin çok büyük rolü vardı. ${ }^{44}$

39 Mustafaev, Kafkasya Türklerin'den Ömer Faik Numanzade'nin Hayatı ve Faaliyetleri (1872-1937), 88.

40 Keykurun, Azerbaycan Ístiklal Mücadelesinin Hatıralarl (1905-1920), 97-98.

41 Keykurun, Azerbaycan Ístiklal Mücadelesinin Hatıralarl (1905-1920), 98-99.

42 Keykurun, Azerbaycan Istiklal Mücadelesinin Hatıralarl (1905-1920), 99.

43 Keykurun, Azerbaycan İstiklal Mücadelesinin Hatıralarl (1905-1920), 99-100.

44 Mustafaev, Kafkasya Türklerin'den Ömer Faik Numanzade'nin Hayatı ve Faaliyetleri (1872-1937), 89. 
Ömer Faik ile Naki Bey Talat Paşa ve Enver Paşa'yla görüştükten sonra amaç ve maksatları hâsıl olmuştur. Onlar İstanbul'da bulundukları zaman Osmanlı Meclis-i Mebusan'ında bulunmuş, oradaki yetkililerle görüşmeler yapmışlardır. ${ }^{45}$ Ayrıca birçok devlet adamlarıyla da temaslarda bulunmuşlardı. İstanbul' da bulundukları zaman çok iyi şekilde karşılanmış, ağırlanmış ve her ikisine saygı ve değer gösterilmiştir.

Ömer Faik Numanzade ile Naki Şeyhzamanlı İstanbul'daki temasları sırasında Osmanlı basınının da ilgisini çekmiştir. 9 Mart 1918'de Tasvir-i Efkâr gazetesi Ömer Faik ile bir mülakat gerçekleştirmiştir. ${ }^{46}$ Ömer Faik Tasvir-i Efkâr gazetesine verdiği röportajda Kafkasya'nın siyasi ve askeri vaziyetiyle ilgili değerlendirmeler yapmıştır.

“1917 Mart ihtilali sonrasında Rusya’da kurulan hükûmetler hakkında bilgi verdikten sonra ihtilallerin Kafkasya’yı nasıl etkilediği üzerinde durdu. Kafkasya'da kurulan hükûmetin Ukrayna ve Finlandiya gibi her hususta serbestçe hareket ettiğini anlatan Ömer Faik Bey, yakın gelecekte her milletin kendi cumhuriyetini kuracağını belirtti. Ömer Faik Bey mülakatında ayrıca Kafkasya'da Müslümanlarla Gürcüler arasında önemli bir ihtilaf olmadığını, fakat asıl sorunun Ermenilerle olduğunu söyledi. Muhabirin "Kafkasya ordusu nasıl dağıldı?" sorusuna ise Kerenski hükûmetinin iktidara gelir gelmez bir grup askeri terhis ettiği, fakat Bolşeviklerin iktidara gelmesinden sonra merkezden terhis emrini beklemeden Rus askerlerinin Kafkas cephesini terk ettikleri cevabını verdi. "Brest-Litovsk'a gidecek yerde niçin buraya geldiniz?” sorusuna ise Ömer Faik Bey, Kafkasya barışının Brest-Litovsk’ta değil İstanbul'da olacağını söyleyerek artık Kafkasya üzerinde Osmanlı hükûmetinin etkili olacağını ima ederek cevap verdi. Ömer Faik mülakatın çeşitli yerlerinde İstanbul'dan kesinlikle ümitli olduklarını belirtti”. ${ }^{47}$

Her iki delege İstanbul'daki işlerini bitirdikten sonra Enver Paşa'nın talimatıyla Kafkasya'ya dönmüşlerdir. Ömer Faik ve Naki Bey memleketlerine döndükten sonra bölgedeki siyasi gelişmelerin hemen ardından Türk ordusu Kafkasya'ya girdi.

\section{Talat ve Enver Paşa'ya Mektubu}

Kafkasyalı delegeler olarak Azerbaycan'1 temsilen Naki Şeyhzamanlı, Ahıska'yı temsilen Ömer Faik yukarıda da ifade edildiği gibi Osmanlı sınırları içerisine dâhil oldukları andan itibaren Samsun, Sivas, Konya, Kayseri ve Mudanya'dan bölgesindeki yetkili idare ve yöneticiler, Dâhiliye Nezareti'ne telgraflar çekerek İstanbul'u bilgilendirmiştir. Ayrıca delegelerin Kafkasya Müslümanlarının arz ve dileklerini Bab-1 Ali’ye ulaştırmak maksadıyla İstanbul'a doğru hârekat etmekte olduklarını bildirilmiştir. ${ }^{48}$

Ömer Faik Numanzade İstanbul'a varmadan önce Anadolu'dayken Başkente Talat Paşa ve Enver Paşa'ya Kafkasya'yla alakalı oldukça ayrıntılı rapor tarzında bir mektup yazmıştır.

45 Keykurun, Azerbaycan İstiklal Mücadelesinin Hatıralarl (1905-1920), 100-101.

46 Sarı, "Kafkas Murahhaslarının İstanbul Seyahati ve Kafkas Cephesi (1918)", 75-100.

47 Sar1, "Kafkas Murahhaslarının İstanbul Seyahati ve Kafkas Cephesi (1918)", 75-100.

48 Şükürov ve Gafarov, Azerbaycan Cumhuriyeti (1918-120), 52-55. 
Mektupta: o dönem Rus İhtilali'nden sonra Kafkasya'daki otorite boşluğundan, Müslümanların yoğunlukta olduğu bölgelerin son vaziyetinden, Ermenilerin Kafkasya'da Müslümanlara karşı yaptıkları faaliyetlerden ve İngilizlerin bölgedeki niyetlerinden bahsetmiştir. Mektubun son bölümünde İran'daki Türklerle Kafkasya' daki Türklerin birleştirilmesiyle bağlı Osmanlı Devleti'nin yetkililerine öneride bulunmuştur. Ayrıca bölgedeki son gelişmelerden dolayı Osmanlı'nın eline büyük bir fırsatın düştüğünü ve Kafkasya'yı ilhak etmesi gerektiğini bildirmiştir. ${ }^{49}$ Ömer Faik Numanzade'nin Osmanlı Devlet yetkilileriyle görüşmesi esnasında onlara verdiği bilgilerin ve yukarıdaki raporunun (mektup) Osmanlı Devleti'nin Kafkasya'yla bağlı faaliyetlerinde etkili ve faydalı olduğu yüksek ihtimaldir. ${ }^{50}$

\section{Türk Ordusunun Kafkasya'ya Girişi}

Brest Litovsk Antlaşmasının imzalanmasından sonra Kafkasya'da gelişen siyasi ve askeri konumdan dolayı Osmanlı Devlet'i Doğu Anadolu'nun kurtarılmasıyla ilgili Türk ordusuna ileri emrini verdi. Vehbi Paşa komutasındaki Türk Askeri birlikleri harekete geçtiler. 25 Nisan 1918'de Kars, 14 Nisan Batum, ardından da Ahıska bölgesi Türk kontrolüne geçti. ${ }^{51}$

Bölgede yapılan referandum sonucu Elviye-i Sealse diye ifade edilen üç sancak ahalisi evet oyu kullanarak Osmanlı'ya birleşmek istediklerini ortaya koydular. 15 Ağustos 1918 tarihinde Elviye-i Selase ahalisinin Osmanlı'ya birleşme isteği Sultan Vahdettin'in fermanı ile resmileşti. (Ahıska Türkleri Osmanlı Devleti tarafından bölgelerinin ilhakını isteseler de bu durum gerçekleşmedi). ${ }^{52}$

Osmanlı Brest Litovsk Antlaşması ile I. Cihan Harbi'nden sonra Kafkasya Cephesinde ilk kez kısmi de olsa bir başarı kazanmıştır. Enver Paşa Kafkasya' da Türk Devletleri veya Büyük bir Türk Devleti'nin kurulmasını istemekteydi. Böyle bir oluşum Rusya ile Osmanlı arasında tampon bölge olması hasebiyle çok önem arz etmekteydi. Osmanlı Ordusu Elviye-i Selase'yi geri almakla kalmamış Bakü’yü kurtarmak için (15 Eylül 1918) Gürcistan ve Ermenistan üzerinden Azerbaycan'a dâhil olarak bölgeyi Ermeni ve Ruslardan temizlemiştir. ${ }^{53}$

1918 yılının Mayısında ileri harekâtı yapan Osmanlı Devleti Elviye-iSelase dışında Müslüman Türklerle meskûn Ahıska bölgesini kendi sınırlarına kattı. ${ }^{54}$ Böylelikle Ömer Faik'in en büyük arzusu olan bölgenin ilhakı meselesi Osmanlı Devleti'nin gündemine gelmiş bulundu. Bölgedeki yetkili kişilere Ahıska'nın ilhakı ile ilgili çalışmalara başlamaları için talimat verildi. Yukarıda da ifade edildiği gibi 15 Ağustos 1918'de Elviye-i Selase'nin ilhak1 onaylandı. Ancak buna karşın Ahıska ve civarındaki Türk toprakları ilhak edilmedi. Ahıska'nın Osmanlı'ya ilhak edilmemesinin en büyük sebebi bölgedeki yetkililerin Ahıska, Ahalkelek,

49 BOA, DH.EUM.5.Şb., 55/26, v.3, s. 1-2.

50 Mustafaev, Kafkasya Türklerin'den Ömer Faik Numanzade'nin Hayatı ve Faaliyetleri (1872-1937), 91.

51 Gökdemir, Cenub-i Garbi Kafkas Hükumeti, 19.

52 Gökdemir, Cenub-i Garbi Kafkas Hükumeti, 20.

53 Gökdemir, Cenub-i Garbi Kafkas Hükumeti, 27-28.

54 Birinci Dünya Harbinde Türk Harbi: Kafkas Cephesi 3 'üncü Ordu Harekâtı, (Ankara: Genelkurmay Basımevi, 1993), II: 524. 
Gümrü ve Sürmeli gibi sancakların ilhakı meselesinin sakıncalı olduğuna dair merkeze yazıp gönderdikleri raporlardan dolayı olmuştur. ${ }^{55}$ Bununla birlikte Ömer Faik'in en büyük arzusu olan Ahıska'nın ilhakı meselesi gerçekleşmemiş, onun Osmanlı devlet ricalinden ilhakla ilgili talep ve ricası yerine getirilmemiştir. Bu bağlamda Ömer Faik'in Ahıska'nın Osmanlı tarafından ilhak edilmediği takdirde neler olacağıyla bağlı tespitleri doğru çıkacaktır. Asırlardan beri Türklüğün bir parçası olan Ahıska tekrar Rusların kontrolüne geçtikten sonra bölgedeki Müslüman Türkler sürgün edilecek ve Türklüğe dair hiç bir ibare bırakılmayacaktır. ${ }^{56}$

8 Ekim 1918'de İttihat ve Terakki Partisi'nin istifası ve 30 Ekim 1918'de Mondros Mütarekesinin imzalanması ile birlikte Türk Ordusu Elviye-i Selase dışındaki Kafkasya topraklarından geri çekilme mecburiyetinde kalmıştır. Böylelikle Azerbaycan, Ahıska ve Gümrü'nün boşaltılmasına karar verilerek Brest Litovsk dışında Osmanlı'nın ele geçirdiği bütün topraklardan 21 Ekim 5 Aralık 1918 tarihleri arasında ordu tahliye edilmiştir. Mondoros Mütarekesi ile birlikte Kafkasya'daki Türkler kendi haline bırakılmış, bölge ahalisi birçok sıkıntılarla karşı karşıya kalmıştır. Ancak Elviye-i Selase ve ona yakın sınır bölgelerindeki Türk ahalisi Ermeni ve Gürcü baskılarına maruz kalmamak için ve de yeni felaketlerle karşılaşmamak için istiklâl mücadelesine girişmişlerdir. ${ }^{57}$

\section{Ahıska Türklerinin Teşkilatlanması}

Mondros Mütarekesinden sonra Türk ordusunun Ahıska'dan geri çekilmesiyle birlikte Kafkasya'daki diğer Türkler gibi Ahıska Türkleri de kendi kaderleriyle baş-başa kalmıştır. Daha önceden Ermeni, Gürcü ve Rus katliamlarına maruz kalan bölge ahalisi yeniden boyunduruk altına girmemek için birtakım siyasi faaliyetler içerisine girmişlerdir. Bu bağlamda 29 Ekim 1918 tarihinde Ahıska Hükûmet-i Muvakkatası kurulmuştur. Türk ordusunun bölgeden çekileceğini duyan Ahıska ve sınırdaki Gümrü, Iğdır ve Nahcivan Türkleri 9. Ordu Kumandanı Yakup Şevki Paşa'ya şu şekilde müracaat etmişlerdir:

\footnotetext{
"a - Osmanlı Hükûmeti askerinin arazimizden geri çekmemesini,

b - Veyahut askeri geri çekme zarureti varsa İslam ahaliyi muhafaza için her kazada bir murahhas ile kâfi miktarda asker bırakmasını, c - Veyahut kazamıza gelecek Hiristiyan ahalinin bizi mahv ve ifna etmemesini ve Hiristiyan askerlerinin de gelmemesini ve sulhu umuminin nihayetine kadar bizi kendi halimize ve müstakil bırakarak Gürcü veya Ermeni hükûmetlerinin dahi bizi şimdilik taht-1 emir ve esaretlerine almamalarına temin edilmesini istiyoruz". ${ }^{58}$
}

Bölge ahalisinin bu müracaatı üzerine Yakup Şevki Paşa, İstanbul Hükûmeti Erkan-1 Harbiye Riyasetinden Ahmet İzzet Paşa'ya telgraf çekerek buradaki Türklere yardım etmeleri

55 Sarı, "Kafkas Murahhaslarının İstanbul Seyahati ve Kafkas Cephesi (1918)", 75-100.

56 Mustafaev, Kafkasya Türklerin'den Ömer Faik Numanzade'nin Hayatı ve Faaliyetleri (1872-1937), 92.

57 Gökdemir, Cenub-i Garbi Kafkas Hükumeti, 34.

58 Gökdemir, Cenub-i Garbi Kafkas Hükumeti, 35-36. 
gerektiğini vurgulamıştır. Ancak Ahmet İzzet Paşa sınır bölgelerindeki Türklere yardım yapamayacaklarını bildirmiştir. Bir sözle İzzet Paşa bölgedeki Türklerin kendi başlarının çaresine bakmasını uygun bir dille ifade etmişti. Bu haberi duyan Ahıska Türkleri telaşa kapılarak Osmanlı içlerine doğru göç etmeye başlamıştır. Ayrıca Ermeni ve Gürcülerin planlı şekilde Ahıska' da yaptıkları yalan haberlerden dolayı Müslüman Türk ahalisi paniğe kapılmıştır. Ahıska' daki Türklerin bir kısmı Anadolu'ya göç etmeyi tercih etse de diğer bir kısmı da kendi memleketlerini Ermeni ve Gürcülerden korumak için teşkilatlanma yoluna gitmiş, kendilerini korumak üzere yöntemler aramışlardı. ${ }^{59}$

\title{
Ahıska Geçici Hükûmeti ve Hükûmet Reisliğine Seçilen Ömer Faik Numanzade
}

Kendi kaderleriyle baş başa kalan Ahıska ahalisi kendisini korumak için bir oluşum kurmak fikrine düşer. Ahıska'yı Ermeni ve Gürcülere ezdirmemek kararını alan bölge ahalisi her türlü saldırıya hazırlıklı olup işgalcileri bölgeye sokmayacaklardır. Bütün bu tehlikelerle yüz yüze kalmış olan Müslüman Türkler, sonunda kendi hükûmetlerini kurmak için harekete geçtiler. Ahıska Türkleri 29 Ekim 1918 tarihinde Ahıska Hükûmet-i Muvakkatası'nı ilan ettiler. Hükûmet başkanlığına Ömer Faik Numanzade seçildi. Numanzade hükûmet başkanlığına seçildikten hemen sonra üçüncü fırka kumandanı Halil Paşa'ya müracaat ederek, Ahıska Hükûmet-i Muvakkatası'nın kuruluş maksadını ve isteklerini Osmanlı Devleti'ne bildirdi. Numanzade'nin Osmanlı'dan talepleri şu şekildedir:

\begin{abstract}
“Hükûmet-i Osmaniye'nin Ahıska ve Ahılkelek kazalarını maazallah tahliye edeceği ihtimaline nazaran, merkezi Ahıska olmak üzere teessüs eden hükûmet-i Muvakkata; Ordu-yu Humayun Kumandanı, muhterem Yakup Şevki Paşa Hazretlerinin himaye-i samilerinin ihtihsal ile yüz bin nufusu haiz mühim bir kütle-i İslamiyeyi düşmana ezdirmemek için üçüncü firkanın Ahıska'da kalmasını talep eyler. Zaten mezkûr fırkanın gaye-i teşkilatı Kafkasya'da bulunup asırlardan beri ezilen üzülen unsur-1 İslam'ı tahriş olduğu malum-1 samileridir. Ve vatan-1 mübarekemizin bilmecburiyye daire-i Osmaniye'den çıktığı takdirde Gürcülere terk edilmeyip sulh-i umumiyenin kabul edileceği esas ve prensiplere göre teşkil edilen demokrat hükûmet-i milliyemizin temin gayesiyle heyet-i idaremiz azasında olan Arabin Efendi murahhas seçilmiş ve kendisine itimatname verilmiş olup, bu itimatnamede lüzumlu bilgiler bulunmaktadır". ${ }^{60}$
\end{abstract}

Ömer Faik Numanzade'nin bu istek ve taleplerini Halit Paşa, Yakup Şevki Paşa’ya ulaştırmıştır. Yakup Paşa'nın cevabından ise Türk Ordusu’nun Ahıska'da kalamayacağı anlaşılmıştır. Ancak bölgedeki Türklerin hiçbir şeyden korkmayarak örgütlenmelerini tavsiye etmiş, her gün değişen siyasi konjonktürden dolayı her an bir firsat doğabileceği mesajını vermişti. Numanzade'nin Osmanlı'ya gönderdiği temsilci heyetiyle görüşen Yakup Şevki Paşa daha önce gönderdiği mesajları kendi ağzıyla tekrar ifade etmişti. ${ }^{61}$ Ancak bölgedeki üçüncü

59 Gökdemir, Cenub-i Garbi Kafkas Hükumeti, 38.

60 Gökdemir, Cenub-i Garbi Kafkas Hükumeti, 38-39.

61 Gökdemir, Cenub-i Garbi Kafkas Hükumeti, 40. 
fırka kumandanı Halit Paşa, Müslüman Türk ahalisini kendi kaderlerine terk etmek istemiyor, ordu geri çekilse bile bölge ahalisine nasıl destek olabileceği planlarını düşünmüştür. ${ }^{62}$

Ahıska'yı işgal için sabırsızlıkla bekleyen Gürcüler, Türk askerinin bölgeden bir an önce çekmesini istiyorlard1. İstanbul Hükûmeti resmen bölgedeki Türk İslam Ahalisini Gürcülerin insafına terk ediyordu. Bu ise tamamen Mondros Mütarekesi'nin bir neticesiydi. Ancak ne Yakup Şevki Paşa ne de Üçüncü Fırka Kumandanı Halit Paşa durumdan memnun değillerdi. Bu durumu kabul etmek istemeyen her iki paşa gizlice görüşerek bir anlaşmaya varırlar. Türk ordusunun içerisinden beş yüze yakın subay ve erleri terhis ederek bölgede milis kuvveti kurdular. Kurulan bu milis kuvvetlerinin idaresine Ahıskalı Server Atabey adlı birisi getirildi. Ayrıca bu kuvvetlerin kendisine yetecek kadar top, makinalı tüfek ve cephane yardımı sağlandı. Böylelikle Ahıska Türkleri, Gürcü işgaline karşı mümkün olduğu kadarıyla kendilerini koruyacaklard1. ${ }^{63}$ Ahıska Türkleri kendilerini Gürcü işgaline karşı korumaya hazırlandıkları bir zamanda Doğu Anadolu'da çok önemli bir gelişme yaşandı. Elviye-iSelase'de bulunan bütün Türklerin bir çatı altında toplamak üzere, Kars İslam Şurası adında bir oluşum kuruldu. Kars İslam Şurası 30 Kasım 1918'de Batum'dan Nahcivan'a kadar olan Müslüman Türklerin yaşadığı bölgelerden temsilciler çağırarak bir kongre yaptı. Bu kongrede Milli İslam Şurası, Kars Milli Şura Hükûmeti olarak adlandırıldı. Milli Şura Hükümeti’ne Batum Aras Türk Hükûmeti gibi Ahıska Hükûmeti de katılarak Ermeni ve Gürcü İşgaline ve katliamlarına karşı kurulan bu yeni oluşumun içerisinde yer ald1 ${ }^{64}$

\section{Ahıska'nın İşgali}

Ekim 1917'de Çarlık rejiminin devrilmesinden sonra Gürcüler ilk önce başında kendilerinin bulunduğu Mavera-i Kafkas Komitesi ve Mavera-i Kafkas Hükûmeti adındaki oluşumların içinde yer aldıktan sonra 26 Mayıs 1918'de kendi bağımsızlıklarını ilan etmiştir. Daha önce Ermeni ve Rus zulümlerine maruz kalmış bölgedeki Müslüman Türkler şimdi de Gürcü baskısına ve işgaline maruz kalmamak ve hürriyetlerini kazanmak maksadıyla harekete geçmişlerdir. Ömer Faik, 1917 yılında itibaren Gürcistan'da Türklerin hürriyet ve haklarını kazanmaları için önemli faaliyetler içerisine girmiş ve bu uğurda mücadele etmiştir. ${ }^{65}$ Yukarıda da ifade edildiği gibi bölgedeki gelişmeler üzerine 29 Ekim 1918'de Ahıska Hükûmet-i Muvakkatası kurulmuş, başkan olarak Ömer Faik Numanzade seçilmiştir. Ömer Faik’in başkanlığını yürüttüğü Ahıska Hükûmeti Kars'ta kurulan ve daha büyük oluşum olan (5 Kasım 1918'de) Kars İslam Şurası'na katılmışlardır. Kars İslam Şurası 30 Kasım'da kendisini Hükûmet olarak ilan etmiştir. Ancak 4 Aralık 1918 yılında Osmanlı ordusunun bölgeden çekilmesi ile birlikte Gürcüler Ahıska’yı işgal

62 Gökdemir, Cenub-i Garbi Kafkas Hükumeti, 42.

63 Gökdemir, Cenub-i Garbi Kafkas Hükumeti, 43; Sar1, “Ahıska’da Son Osmanlı İdaresi (1918)”, 153-179.

64 Gökdemir, Cenub-i Garbi Kafkas Hükumeti, 43; Mustafaev, Kafkasya Türklerin'den Ömer Faik Numanzade’nin Hayatı ve Faaliyetleri (1872-1937), 95.

65 Gurbanov, Ömer Faik Numanzade, 114; Faik, “Ömer Faik Efendinin Ruhadze'nin Telegramına Cevabı”, 2. 
etmişlerdir. ${ }^{66}$ Doğudaki Türkler Ermeni ve Gürcü işgallerini engellemek için 17 Ocak 1919'de Cenub-i Garbi Kafkas Hükûmet-i Muvakkatasını kurduklarını ilan ettiler. ${ }^{67}$ Bu hükûmette Ahıska Türklerine de temsil hakkı verilmiştir. Nitekim bu yeni oluşuma ait Müslüman-Türk birlikleri 2 Şubat 1919'de Ahıska bölgesini Gürcülerden geri almışlardır. ${ }^{68}$ Kısa zaman içerisinde Ahıska bölgesi merkezi Kars’ta bulunan Türk hükûmetiyle Gürcüler arasında bir kaç defa el değiştirdi. ${ }^{69} 22$ Nisan 1919'de İngilizlerin bölgeye müdahalesiyle Cenub-i Garbi Kafkas Hükümeti'nin varlığına son verildi. ${ }^{70}$ Bununla Ahıska'daki Türk hâkimiyeti de sona ermiştir.

\section{Sonuç}

Ömer Faik Numanzade'nin Kafkasya Türklerinin milli basınının gelişiminde yaptığ işler ve Azerbaycan eğitim tarihinde açtığı çığır, Güney Kafkasya'da Türk varlığının kendini ispatında ve devamlılığını korumasında çok önemli bir etken olmuştur. Bununla birlikte onun siyasi faaliyetleri de Kafkasya Türk tarihinde çok önemli yere sahiptir. I. Cihan Harbi sırasında bölgede gelişen olaylar üzerine Ömer Faik, Kafkasya ve Doğu Anadolu Türklerinin Rus, Ermeni ve Gürcüler karşısında yok olmaması için siyasi faaliyetlere girişmiş, bu uğurda işkenceleri ve tutuklanmaları göze alarak milleti için hiç bir vazifeden kaçmamıştır. Aynı zamanda kendi toplumu olan Ahıska Türklerinin milli mücadelesini başlatan Ömer Faik bütün varlığıyla hayatını uğurda ortaya koymuştur.

1917 Rus İnkılâbı ile bölgede gelişen olaylardan sonra Ömer Faik, Kafkasya Türklerinin varlıklarını koruması için Osmanlı'ya muhtaç olduğunu, Türk ordusunun Kafkasya'yı ilhak etmesi gerektiğini savunmuştur. Bunun için İstanbul'da bulunmuş, Enver ve Talat Paşa ile görüşerek milli talepleri dile getirmiştir. Ömer Faik'in İstanbul'daki temasları işe yaramış, o, Kafkas İslam Ordusunun Kafkasya’ya girmesine vesile olmuştur. Ayrıca Numanzade’nin Talat ve Enver Paşa'lardan İran Türklüğü ile Kafkasya Türklüğünün birleştirmelerini istemiştir. Numanzade'nin Rusya'nın iç meseleleriyle uğraştığı bir dönemde fırsatı kaçırmayarak en azından Osmanlı, Kafkasya ve İran'ın kuzeyini kapsayacak büyük bir Türk devletinin kurulmasını istediğini görmekteyiz. Mondros Mütarekesinin imzalanması ile birlikte Türk ordusu Kafkasya topraklarından geri çekilmek mecburiyetinde kalmıştır. Osmanlı Kafkasya'da tutunamayınca Ömer Faik de Ahıska Türklerini örgütleyerek milli mücadelelerini başlatmıştır. Bunun sonucu olarak 29 Ekim 1918 tarihinde Ahıska Hükûmeti kurulmuş, kendisi de bu hükûmetin başkanlığını yapmıştır. Ancak bu hükûmet kısa ömürlü olmuştur. Ömer Faik, Ahıska Türklerinin bağımsızlığı için hem dönemin Gürcü hükûmetiyle hem de ki Ermeni çeteleriyle mücadele etmiş, Türklerin haklarını savunmak ve mevcudiyetlerini devam ettirmeleri için elinden geleni yapmıştır.

66 Gökdemir, Cenub-i Garbi Kafkas Hükumeti, 78.

67 Fahrettin Kırzıoğlu, "Cenûbu-Garbî Kafkas Cumhuriyeti (Kars Milli-Şûrâ Hükûmeti)”, Türk Kültürü 6/72 (1968), 961

68 Gökdemir, Cenub-i Garbi Kafkas Hükumeti, 127.

69 Mustafa Sarı, “I. Dünya Savaşı'ndan Sonra Ahıska ve Civarında Türk Teşkilatlanması”, Yeni Türkiye 78 (Ekim 1918-Nisan 1919), 309-323.

70 Fahrettin Kırzıoğlu, Kars Tarihi, (İstanbul: Işı1 Matbaası, 1953), I: 558. 
Hakem Değerlendirmesi: Dış bağımsız.

Çıkar Çatışması: Yazar çıkar çatışması bildirmemiştir.

Finansal Destek: Yazar bu çalışma için finansal destek almadığını beyan etmiştir.

Peer-review: Externally peer-reviewed.

Conflict of Interest: The author has no conflict of interest to declare.

Grant Support: The author declared that this study has received no financial support.

\section{Kaynakça/References}

Birinci Dünya Harbinde Türk Harbi: Kafkas Cephesi 3 'üncü Ordu Harekâtı. 2 cilt. Ankara: Genelkurmay Basımevi, 1993.

BOA, DH.EUM.5.Şb., 55/26, v.3, s. 1-2.

Edward David Allen, William. Paul Muratoff, Kafkas Harekâtı (1828-1921): Türk-Kafkas Sinırındaki Harplerin Tarihi. Ankara: Genelkurmay Basımevi, 1966.

Gökdemir, Ahmet Ender. Cenub-i Garbi Kafkas Hükumeti. Ankara: Türk Kültürü Araştırma Enstitüsü Yayınları, 1989.

Gurbanov, Şamil, Seçilmiş Eserler-Ömer Faik Numanzade. Şark-Garb Yayınları, Bakü 2006.

Gurbanov, Şamil. Ömer Faik Numanzade. Bakü: Gençlik Yayınları, 1992.

Keykurun, Naki. Azerbaycan İstiklal Mücadelesinin Hatıraları. İstanbul: İstanbul Ekspress Matbaası, 1964.

Kırzıoğlu, Fahrettin. "Cenûbu-Garbî Kafkas Cumhuriyeti (Kars Milli-Şûrâ Hükûmeti)”, Türk Kültürü 6/72 (1968): 961.

Kırzıoğlu, Fahrettin. Kars Tarihi. 1 cilt. İstanbul: Işı1 Matbaası, 1953.

Kurat, Aktes Nimet. Türkiye ve Rusya. Ankara: Ankara Üniversitesi Basımevi, 1970.

Numanzade, "Yardım Tecili Lazım", İkbal, 19 Ocak 1915.

Ömer Faik Numanzade, “Ben Kimim?”, Gardaş Kömeyi [Yardımı]. Bakü: Müherrirler Neşriyatı, 1917.

Ömer Faik, “Ömer Faik Efendinin Ruhadze'nin Telegramına Cevabı”, Azerbaycan, 9 Mart 1919.

Rzayev, Sahib. “Ömer Faik Numanzade'nin Edebi-Publist Faaliyeti”. Doktora Tezi, Azerbaycan İlimler Akademisi Nizami Adına Edebiyat Enstitüsü, 1973.

Sarı, Mustafa. “Ahıska'da Son Osmanlı İdaresi (1918)”, Karadeniz Araştırmaları Dergisi 46 (2015): 153-179.

Sarı, Mustafa. "I. Dünya Savaşı'ndan Sonra Ahıska ve Civarında Türk Teşkilatlanması”, Yeni Türkiye 78 (Ekim 1918-Nisan 1919): 309-323.

Sarı, Mustafa. "Kafkas Murahhaslarının İstanbul Seyahati ve Kafkas Cephesi (1918)", Kafkas Çalı̧̧maları: Sosyal Bilimler Dergisi 2 (Mart 2016): 75-100.

Şahin, Enis. Türkiye ve Maverâ-yı Kafkasya ilişkileri içerisinde Trabzon ve Batum konferansları ve Antlaşmaları (1917-1918). Ankara: Türk Tarih Kurumu, 2002.

Şükürov, Giyas. Vasif Gafarov. Azerbaycan Cumhuriyeti (1918-120). İstanbul: Teas Press Yayınları, 2018.

Tuğaç, Hüsamettin. Bir Neslin Dramı. İstanbul: Çağdaş Yayınları, 1975. 
